\title{
OTONOMI DAERAH DAN DESENTRALISASI PENDIDIKAN
}

(Studi Pada Jenjang Pendidikan Menengah Dinas Pendidikan Kota Sawahlunto)

\section{Novendra Hidayat, S.IP., M.Si.}

\begin{abstract}
This study aimed to describe and analyze the implementation of decentralization in educational management in Sawahlunto, specifically in School Based Management (SBM) at the level of secondary education. It uses the concept of decentralization, Educational Management, and School-Based Management (SBM). This study applies a qualitative approach design of descriptive analysis case study and collecting the data by interviewing and documentation. Informants were selected by purposive sampling. The study shows the implementation of decentralization in educational management particularly in the implementation at the level of secondary education must be completed so it can be more optimal. In its implementation efforts, carried out the stages to improve the performance of school management organizations, the management of human resources, teaching-learning process, administrative resources, Educational Services School-Based Management, and Quality Improvement of Education and Manpower Education. The local government is currently implementing the three pillars of educational development. In accordance with the Local Government Work Plan (RKPD), School-Based Management Improvement Program is one of the Educational Department programs. It is one form of decentralization in educational management, the implementation is expected to improve the quality of education in Sawahlunto at every level of education.
\end{abstract}

Keywords: Decentralization, Education Management, School-BasedManagement (SBM)

\section{PENDAHULUAN}

\section{I.1. Latar Belakang}

Sumber daya manusia (SDM) merupakan salah satu pilar pembangunan bangsa disamping pembangunan sumber daya alam dan teknologi. Dalam hal pembangunan sumber daya manusia, pendidikan merupakan salah satu sektor strategis yang perlu menjadi fokus perhatian. Hal ini mengingat pendidikan merupakan salah satu sarana untuk meningkatkan kecerdasan dan keterampilan manusia (Ahmad Ali Riyadi, 2006). Dengan demikian kualitas sumber daya manusia tergantung dari kualitas pendidikannya, oleh karena itu berbagai inovasi harus perlu terus dilakukan pemerintah agar kualitas pendidikan semakin meningkat.

Pelaksanaan otonomi daerah sebagaimana diatur dalam Undang-Undang No. 22 Tahun 1999 tentang Pemerintahan Daerah, yang kemudian direvisi menjadi Undang-Undang No. 32 Tahun 2004 tentang Pemerintahan Daerah, dan terakhir menjadi Undang-Undang No. 23 Tahun 2014 tentang Pemerintah Daerah bermakna pengakuan adanya daerah otonom dan sekaligus pengakuan/penyerahan wewenang, hak, dan kewajiban untuk mengelola urusan pemerintahan di bidang tertentu dari Pemerintah kepada Daerah. Termasuk pula di dalamnya berbagai kemungk- 
inan pengelolaan dan pengembangan bidang pendidikan, dimana terdapat perubahan pengelolaan pendidikan dari yang bersifat sentralistik kepada yang lebih bersifat desentralistik.

Penyelenggaraan otonomi pendidikan ini dipertegas dalam UU No. 20 Tahun 2003 tentang Sistem Pendidikan Nasional (Sisdiknas), yang menegaskan tentang pergeseran paradigma pendidikan nasional, dari education for all (pendidikan untuk semua) menjadi education from all, by all, and for all (pendidikan dari semua, oleh semua dan untuk semua) (Sirozi, 2005). Dalam penyelenggaraan desentralisasi pendidikan, pemerintah daerah sebagai pemilik otoritas tertinggi di daerah memiliki kewenangan dalam hal pengaturan, pengurusan, pembinaan, serta pengawasan. Karenanya komitmen dari pemerintah daerah dalam penyelenggaraan desentralisasi pendidikan adalah suatu hal yang sangat diperlukan. Pemerintah daerah diharapkan menciptakan strategi dan inovasi dalam pelaksanaan desentralisasi pendidikan di daerahnya masing-masing. Pemerintah Daerah mengetahui dan mengerti apa yang seharusnya dapat dilaksanakan dalam upaya meningkatkan kualitas pendidikan di daerahnya.

Pelaksanaan desentralisasi pendidikan di Kota Sawahlunto, sesuai dengan amanat Undang-Undang Dasar yang dituangkan dalam UU No. 22 Tahun 1999 tentang Pemerintahan Daerah yang kemudian direvisi dengan UU No.32 Tahun 2004 tentang Pemerintahan Daerah, dimana sejak tahun 2001 telah melaksanakan desentralisasi pendidikan.

Sejauh ini, Kota Sawahlunto dikenal sebagai salah satu daerah yang memiliki komitmen yang tinggi dalam penyelenggaraan desentralisasi pendidikan. Hal ini terlihat dari Rencana Strategis Kota Sawahlunto di bidang pendidikan, yang meliputi tiga hal diantaranya: perluasan dan pemerataan akses pendidikan; peningkatan mutu, relevansi, dan daya saing pendidikan; dan penguatan tata kelola, akuntabilitas, dan citra publik pendidikan (pendidikan bermutu, akuntabel, murah, merata, dan terjangkau oleh rakyat banyak). Dukungan pemerintah kota juga terlihat dari alokasi anggaran pendidikan yang diberikan untuk pendidikan pada tahun 2008, yaitu 24\% dari dana APBD Kota Sawahlunto yakni sebesar 76.411.046.867. Dana yang diberikan sebesar itu tentunya merupakan suatu bentuk motivasi yang tinggi agar penyelenggaraan pendidikan di kota ini bisa menjadi lebih baik lagi.

Pendidikan menengah merupakan jenjang pendidikan yang mempersiapkan tenaga-tenaga yang kompetitif, yang dipersiapkan untuk menghadapi persaingan global. Sekaitan dengan pendidikan menengah di Kota Sawahlunto saat ini Dinas Pendidikan Kota Sawahlunto terus melakukan pembenahan agar meningkatnya kualitas pendidikan. Berbagai kegiatan dilaksanakan dalam upaya peningkatan kualitas pendidikan pada pendidikan menengah di Kota Sawahlunto. Diantara kegiatan itu diantaranya magang guru di sekolah favorit SMA 1 dan SMK 2 Yogyakarta, pembangunan Iptek center, dan orientasi kepala sekolah dan pengawas serta tenaga kependidikan ke sekolah menengah Kebangsaan Malaysia.

Meskipun di masing-masing daerah standar pendidikan berbeda-beda, untuk Kota Sawahlunto dari segi partisipasi pendidikan tergolong tinggi karena boleh dikatakan tidak ada penduduk Kota Sawahlunto yang tidak bersekolah. Angka partisipasi pendidikan Kota Sawahlunto dapat dilihat pada tabel berikut: 
TABEL 1. 1

ANGKA PARTISIPASI PENDIDIKAN DI KOTA SAWAHLUNTO

TAHUN PELAJARAN 2007/2008

\begin{tabular}{|c|c|c|c|c|c|}
\hline \multirow{2}{*}{ No } & \multirow{2}{*}{$\begin{array}{c}\text { Keca- } \\
\text { matan }\end{array}$} & $\begin{array}{c}\text { Ter- } \\
\text { masuk } \\
\text { Paket } \\
\text { C }\end{array}$ & $\begin{array}{c}\text { Tdk. } \\
\text { ter- } \\
\text { masuk } \\
\text { Paket C }\end{array}$ & $\begin{array}{c}\text { Ter- } \\
\text { masuk } \\
\text { Paket C }\end{array}$ & $\begin{array}{c}\text { Tdk. } \\
\text { ter- } \\
\text { masuk } \\
\text { Paket } \\
\text { C }\end{array}$ \\
\hline 1 & $\begin{array}{c}\text { Silung- } \\
\text { kang }\end{array}$ & 35,65 & 29,03 & 26,66 & 23,43 \\
\hline 2 & $\begin{array}{c}\text { Lembah } \\
\text { Segar }\end{array}$ & 85,79 & 85,79 & 80,13 & 80,13 \\
\hline 3 & Barangin & 75,92 & 75,92 & 52,62 & 52,62 \\
\hline 4 & Talawi & 97,50 & 93,96 & 81,79 & 80,44 \\
\hline & Rata-rata & 77,39 & 75,02 & 63,57 & 62,52 \\
\hline
\end{tabular}

Sumber: Dinas Pendidikan Kota Sawahlunto, Tahun 2007

Pada Tabel 1.1 Angka Partisipasi Kasar (APK) dan Angka Partisipasi Murni (APM) Tingkat SMA/SMK/MA Kota Sawahlunto Tahun Pelajaran 2007/2008, dapat dilihat angka partisipasi pendidikan tingkat SMA/SMK/MA berada pada angka 77,39 persen. Angka ini lebih rendah dibandingkan partisipasi pendidikan pada pendidikan dasar (SD/MI), maupun pendidikan menengah pertama (SMP/MTs) yang rata-rata berkisar antara 104,10 persen sampai 111,93 persen.

Dari output yang diperoleh, dalam hal peringkat kelulusan pada ujian nasional SMA/MA/ SMK di tingkat Sumbar, Kota Sawahlunto pada tahun 2007 untuk SMK berada pada peringkat 6 di Sumatera Barat. Sedangkan SMA berada di peringkat 9 jurusan IPA, dan peringkat 6 jurusan IPS dari 19 daerah Kabupaten/Kota yang ada di Provinsi Sumatera Barat. Bahkan untuk SMK, pada hasil ujian nasional tahun 2007, dengan rata-rata nilai 8,12; Kota Sawahlunto pernah menempati urutan 1 secara nasional bersama Kabupaten Probolinggo.

Manajemen atau pengelolaan pendidikan dalam hal ini adalah suatu proses kerjasama yang sistematik, sistemik dan komprehensif dalam rangka mewujudkan tujuan pendidikan. Dalam pelaksanaan desentralisasi pendidikan diperlukan suatu manajemen pendidikan yang baik. Pelaksanaan manajemen pendidikan di Kota Sawahlunto saat ini terlihat masih jauh dari kata menggembirakan. Manajemen pendidikan yang dilaksanakan saat ini masih menunjukkan beberapa kelemahan yang signifikan dan perlu diperbaiki.

Dari pengamatan awal peneliti, konsep manajemen pendidikan masih belum dilaksanakan secara maksimal. Ini ditandai oleh masih ditemukannya di lapangan minimnya pelayanan yang diberikan pendidik dan tenaga kependidikan dalam melaksanakan manajemen pendidikan. Hal ini dimungkinkan oleh masih adanya beberapa pendidik maupun tenaga kependidikan yang memiliki pemahaman yang rendah terhadap konsep manajemen pendidikan tersebut.

Dalam hal pelaksanaan Manajemen Berbasis Sekolah (MBS) sebagai wujud pelaksanaan desentralisasi pengelolaan pendidikan terlihat juga belum dilaksanakan dengan baik. Ini ditandai dengan masih belum optimalnya pelayanan pendidikan yang dilaksanakan oleh sekolah. Minimnya pelayanan yang diberikan sekolah, salah satu contohnya: ketika beruurusan dengan sekolah, adakalanya urusan yang seharusnya dapat diselesaikan dengan segera, terkadang harus menunggu lama untuk proses penyelesaiannya.

Penyelenggaraan otonomi daerah dalam hal desentralisasi pengelolaan pendidikan ini menghendaki pelayanan kepada masyarakat dapat menjadi lebih baik, dan pembangunan daerah juga dapat lebih terarah dengan semakin baiknya sumber daya daerah yang ada. Semua itu tentu saja tidak terlepas dari kontribusi sektor pendidikan. Oleh sebab itu dalam penelitian ini, peneliti tertarik untuk melihat Pelaksanaan Desentralisasi 
dalam Pengelolaan Pendidikan di Era Otonomi Daerah khususnya pelaksanaan Manajemen Berbasis Sekolah (MBS) pada jenjang Pendidikan Menengah di Kota Sawahlunto.

\section{I.2. Rumusan Masalah}

Diperlukan pengelolaan pendidikan yang baik dalam pelaksanaan desentralisasi pendidikan. Terdapat beberapa kelemahan yang signifikan dalam pengelolaan pendidikan di Kota Sawahlunto dan karena itu perlu terus disempurnakan. Manajemen Berbasis Sekolah (MBS) sebagai wujud pelaksanaan desentralisasi pendidikan terlihat belum dilaksanakan dengan sebagaimanamestinya, ini ditandai dengan belum optimalnya pelayanan pendidikan yang dilaksanakan oleh sekolah. Mengingat hal demikian peningkatan kualitas pendidik dan tenaga kependidikan merupakan kebutuhan yang mendesak dan perlu segera dilaksanakan. Dari permasalahan tersebut maka rumusan permasalahan dalam penelitian ini adalah "Bagaimana Otonomi Daerah dan Desentralisasi Pendidikan di Kota Sawahlunto (Studi Pada Jenjang Pendidikan Menengah)?”

\section{I.3. Tujuan Penelitian}

Penelitian ini bertujuan untuk mendeskripsikan dan menganalisis pelaksanaan otonomi daerah dan desentralisasi pendidikan di Kota Sawahlunto khususnya pelaksanaan pengelolaan pendidikan melalui Manajemen Berbasis Sekolah (MBS) pada Jenjang Pendidikan Menengah.

\section{TINJAUAN PUSTAKA}

Untuk membantu peneliti dalam menganalisis temuan penelitian, ada beberapa konsep yang akan dipakai peneliti, yaitu :

\section{II.1. Konsep Otonomi Daerah}

Otonomi dalam bahasa Inggris yaitu outon- omy berasal dari bahasa Yunani otonomia, outo berarti sendiri, nomos berarti hukum atau peraturan. Dalam kamus bahasa Indonesia, otonomi diartikan "Pemerintahan Sendiri". Sedangkan Desentralisasi secara etimologi istilah ini berasal dari bahasa latin, de berarti lepas dan contium berarti pusat. Oleh karena itu desentralisasi diartikan melepaskan diri dari pusat. Desentralisasi berangkat dari pengakuan atas otoritas pusat yang diserahkan ke daerah.

Oleh karena itu, Otonomi Daerah merupakan kewenangan dari daerah otonom untuk mengatur dan mengurus kepentingan masyarakat setempat menurut prakarsa sendiri berdasarkan aspirasi/ keinginan masyarakat sesuai dengan peraturan perundang-undangan yang berlaku. Otonomi daerah tidak saja memaparkan mengenai hak-hak daerah, akan tetapi juga memunculkan berbagai kewajiban bagi pemerintah daerah. Pada UU No. 32 Tahun 2004 pasal 14 ditetapkan urusan pemerintahan pemerintah Kabupaten/Kota yang bersifat wajib dan pilihan. Urusan pemerintahan yang bersifat wajib mencakup urusan-urusan yang berskala kabupaten/kota, yaitu:

1. Perencanaan dan pengendalian pembangunan

2. Perencanaan, pengawasan, dan pemenfaatan tata ruang

3. Penyelenggaraan ketertiban umum dan ketentraman masyarakat

4. Penyediaan sarana dan prasaranan umum

5. Penanganan bidang kesehatan

6. Penyelenggaraan bidang pendidikan dan alokasi SDM potensial

7. Penanggulangan masalah sosial

8. Pelayanan bidang ketenagakerjaan

9. Pasilitasi pengembangan koperasi, usaha kecil, dan menengah

10. Pengendalian lingkungan hidup

11. Pelayanan pertanahan 
12. Pelayanan kependudukan dan catatan sipil

13. Pelayanan administrasi umum pemerintahan

14. Pelayanan administrasi penanaman modal

15. Penyelengaraan pelayanan dasar lainnya, dan

16. Urusan wajib lainnya yang diamanatkan oleh peraturan perundang-undangan.

Adapun urusan yang bersifat pilihan meliputi urusan pemerintahan yang secara nyata ada dan berpotensi untuk meningkatkan kesejahteraan masyarakat sesuai dengan kondisi, kekhasan, dan potensi unggulan daerah yang bersangkutan.

\section{II.2.Desentralisasi dan Desentralisasi Pendi- dikan}

Menurut Hasbullah (2006), desentralisasi adalah pelimpahan wewenang yang disertai keleluasaan daerah dalam menyelenggarakan fungsi pemerintahan sedemikian rupa sehingga pelayanan kepada masyarakat akan menjadi lebih baik, disamping pembangunan daerah dapat lebih terarah dan optimal. Desentralisasi pendidikan merupakan satu aktivitas politik, yakni proses transfer otoritas dalam bidang pendidikan dari pemerintah pusat ke pemerintah daerah dan dari pemerintah ke masyarakat (Sirozi, 2005). Desentralisasi pendidikan disini berarti pelimpahan kekuasaan dan wewenang yang lebih luas kepada daerah untuk membuat perencanaan dan mengambil keputusannya sendiri dalam mengatasi permasalahan yang dihadapi di bidang pendidikan.

Desentralisasi pendidikan tentu saja menjadi perhatian para pemimpin politik dan pembuat kebijakan (policy makers), karena desentralisasi pendidikan sangat politis (intensely political): yaitu merupakan satu isu yang mempengaruhi masa depan sebagian masyarakat. Dampak dari desentralisasi pendidikan ini yaitu pemerintah daerah harus lebih bersungguh-sungguh dalam memikirkan apa-apa yang dibutuhkan untuk pengembangan pendidikan di daerahnya, serta sekolah juga harus lebih aktif dan kreatif sehingga tidak hanya menunggu petunjuk dari atas.

Pemberlakuan sistem desentralisasi akibat pemberlakuan Undang-Undang No. 32 Tahun 2004 tentang otonomi pemerintahan daerah, memberi dampak terhadap pelaksanaan pada manajemen pelayanan pendidikan yaitu manajemen yang memberi ruang gerak yang lebih luas kepada pengelolaan pendidikan untuk menemukan strategi berkompetisi dalam era kompetitif mencapai output pendidikan yang berkualitas dan mandiri. Kebijakan desentralisasi akan berpengaruh secara signifikan dengan pembangunan pendidikan.

Berdasarkan PP No. 38 Tahun 2007 tentang Pembagian Urusan Pemerintahan Antara Pemerintah, Pemerintahan Daerah Provinsi, dan Pemerintahan Daerah Kabupaten/Kota telah dijelaskan mengenai pembagian urusan pemerintahan di bidang pendidikan. Bagi pemerintahan daerah Kabupaten/Kota, diantaranya memiliki kewenangan/urusan untuk:

1) Menetapkan kebijakan operasional, perencanaan operasional pendidikan,

2) Penyelenggaraan dan/atau pengelolaan pendidikan berbasis keunggulan lokal pada pendidikan dasar dan menengah,

3) Pengawasan pelaksanaan kurikulum tingkat satuan pendidikan pada pendidikan dasar, pembinaan dan pengembangan pendidik dan tenaga kependidikan pendidikan anak usia dini, pendidikan dasar, pendidikan menengah dan pendidikan nonformal,

4) Koordinasi, fasilitasi, monitoring, dan evaluasi pelaksanaan ujian sekolah skala Kabupaten/Kota,

Kewenangan-kewenangan yang dimiliki oleh Pemerintah Kabupaten/Kota tersebut dilimpahkan ke Dinas Pendidikan di mas- 
ing-masing Kabupaten/Kota. Sebagaimana yang tercantum pada pasal 3 PP No. 38 Tahun 2007, urusan pemerintahan yang diserahkan kepada daerah disertai dengan sumber pendanaan, pengalihan sarana dan prasarana, serta kepegawaian. Dengan adanya pembagian urusan yang jelas di bidang pendidikan, Dinas Pendidikan bisa membuat program kerja sebagai acuan kerja instansinya sehingga bisa dilihat dengan program kerja yang telah disusun dan dilaksanakan tersebut, desentralisasi pendidikan dapat dilaksanakan dengan baik.

Desentralisasi pendidikan mencakup dua hal (Direktorat PLP Depdiknas, 2002) yaitu:
a) Manajemen berbasis lokasi/ Manajemen Berbasis Sekolah (MBS)
b) Inovasi kurikulum

Pada dasarnya manajemen berbasis lokasi dilaksanakan dengan meletakkan semua urusan penyelenggaraan pendidikan di sekolah. Pengurangan administrasi pusat adalah konsekuensi dari yang pertama dengan diikuti pendelegasian wewenang dan urusan pada sekolah. Inovasi kurikulum menekankan pada pembaharuan kurikulum sebesar-besarnya untuk meningkatkan kualitas dan persamaan hak bagi semua peserta didik. Kurikulum disesuaikan benar dengan kebutuhan peserta didik di daerah atau sekolah. Hal ini sesuai dengan UU No. 20/2003 tentang Sistem Pendidikan Nasional Pasal 38 ayat 2 yang menyatakan bahwa "Kurikulum pendidikan dasar dan menengah dikembangkan sesuai dengan relevansinya oleh setiap kelompok atau satuan pendidikan dan komite sekolah/madrasah di bawah koordinasi dan supervisi dinas pendidikan atau kantor Departemen Agama Kabupaten/ Kota untuk pendidikan dasar dan Provinsi untuk pendidikan menengah". Keputusan Menteri Nomor 22/2006, dan 23/2006 tentang Standar Isi dan Standar Kompetensi Lulusan menjadi dasar pengembangan kurikulum sekolah yang disebut KTSP (Kurikulum Tingkat Satuan Pendidikan).

Dalam pengembangan kurikulum, daerah diberi keleluasaan untuk mengembangkan silabus yang sesuai dengan kebutuhan peserta didik dan tuntutan daerah. Pada umumnya program pendidikan yang tercermin dalam silabus sangat erat kaitannya dengan program-program pembangunan daerah. Manajemen berbasis lokasi yang merujuk ke sekolah, akan meningkatkan otonomi sekolah dan memberikan kesempatan kepada tenaga sekolah, orangtua, siswa, dan anggota masyarakat dalam pembuatan keputusan.

\section{II.3.Manajemen Pendidikan dan Manajemen Berbasis Sekolah}

Manajemen (Pengelolaan) Pendidikan adalah suatu proses kerjasama yang sistamatik, sistemik dan komprehensif dalam rangka mewujudkan tujuan pendidikan (SIEN Consultant, 2009). Selain itu, manajemen pendidikan juga dapat diartikan sebagai segala sesuatu yang berkenaan dengan pengelolaan proses pendidikan untuk mencapai tujuan yang telah ditetapkan. Manajemen atau pengelolaan merupakan komponen integral dan tidak dapat dipisahkan dari proses pendidikan secara keseluruhan. Karena tanpa manajemen tidak mungkin tujuan pendidikan dapat terwujud secara optimal, efektif, dan efisien.

Dalam kerangka inilah akan tumbuh kesadaran akan arti pentingnya Manajemen Berbasis Sekolah (MBS) yang memberikan kewenangan yang seluas-luasnya kepada pihak sekolah untuk mengelola berbagai sumber daya pendidikan dengan melibatkan peran serta masyarakat sebagai lingkungan pendukung. Melalui pelaksanaan MBS diharapkan dapat meningkatkan efektifitas dan efisiensi dalam peningkatan mutu pendidikan. Kebijakan ini sebagai solusi alternatif dari sistem manajemen terpusat yang dianggap 
kurang kondusif dalam melibatkan peran serta masyarakat. Selain itu MBS merupakan upaya demokratisasi dan penghormatan terhadap budaya lokal.

Secara umum pelaksanaan Manajemen Berbasis Sekolah (MBS) dapat dilihat pada 4 (Empat) tahap, yakni: Planning (perencanaan), Organizing (pengorganisasian), Actuating (pelaksanaan), dan Controlling (pengawasan). Pada penelitian ini, akan dilihat pelaksanaan Manajemen Berbasis Sekolah (MBS) pada ke empat tahap tersebut. Berikut ini definisinya secara singkat :

1) Planning (perencanaan);

Planning (perencanaan) adalah pemilihan atau penetapan tujuan organisasi dan penentuan strategi, kebijaksanaan, program, prosedur, anggaran dan standar yang dibutuhkan untuk mencapai tujuan.

2) Organizing (pengorganisasian); Organizing (pengorganisasian) adalah tindakan mengusahakan hubungan-hubungan kelakuan yang efektif antara orang-orang, sehingga mereka dapat bekerja sama secara efisien, dan memperoleh kepuasan pribadi dalam melaksanakan tugas-tugas tertentu, dalam kondisi lingkungan tertentu guna mencapai tujuan atau sasaran tertentu.

3) Actuating (pelaksanaan); dan

Actuating (pelaksanaan) adalah usaha menggerakkan anggota-anggota kelompok sedemikian rupa hingga mereka berkeinginan dan berusaha untuk mencapai sasaran perusahaan dan sasaran anggota-anggota perusahaan tersebut oleh karena para anggota itu juga ingin mencapai sasaran-sasaran tersebut.

4) Controlling (pengawasan); Controlling (pengawasan) adalah suatu kegiatan yang berusaha untuk mengendalikan agar pelaksanaan dapat berjalan sesuai den- gan rencana dan memastikan apakah tujuan organisasi tercapai.

Perkembangan manajemen pendidikan di Indonesia pada orde baru sangat diwarnai dengan manajemen yang sentralistik, kemudian pada era reformasi berkembang menjadi desentralisasi atau dikenal dengan Manajemen Berbasis Sekolah (MBS) yang intinya sekolah diberi wewenang untuk mengatur semua kegiatan sekolah. Ini seiring dengan pemberian wewenang pemerintah pusat pada pemerintah daerah (otonomi daerah).

Dasar pelaksanaan Manajemen Berbasis Sekolah (MBS) adalah Pasal 51 UU Sistem Pendidikan Nasional No. 20/2003. Dimana pada pasal tersebut menyatakan bahwa pengelolaan satuan pendidikan anak usia dini, pendidikan dasar, dan pendidikan menengah dilaksanakan berdasarkan standar pelayanan minimal dengan prinsip manajemen berbasis sekolah. Manajemen Berbasis Sekolah (MBS) merupakan konsep pengelolaan sekolah yang ditujukan untuk meningkatkan mutu pendidikan di era desentralisasi pendidikan. Direktorat PLP Departemen Pendidikan Nasional (2002) menyebutkan pelaksanaan Manajemen Berbasis Sekolah (MBS) dapat dilihat dari 2 (dua) aspek, yakni: (1) Aspek Manajemen Pelayanan Pendidikan yang Berbasis Sekolah, dan (2) Aspek Tenaga Pendidik dan Kependidikan.

Secara konseptual ada beberapa istilah yang berkaitan dengan Manajemen Berbasis Sekolah (MBS), di antaranya School Based Management atau School Based Decision Making and Management. Konsep dasar MBS adalah mengalihkan pengambilan keputusan dari pusat, kanwil, kandep, dinas ke level sekolah (Samani, 1999: 6). Mulyasa (2004: 11) mengutip pendapat Bank Dunia (1999) memberi pengertian bahwa MBS merupakan bentuk alternatif sekolah dalam program desentralisasi di bidang pendidikan, yang ditandai oleh otonomi luas di tingkat sekolah, 
partisipasi masyarakat, dan dalam kerangka kebijakan pendidikan nasional.

Definisi yang lebih luas tentang MBS dikemukakan oleh Wohlstetter dan Mohrman (1996), yaitu sebuah pendekatan politis untuk mendesain ulang organisasi sekolah dengan memberikan kewenangan dan kekuasaan pada partisipan sekolah pada tingkat lokal guna memajukan sekolahnya. Partisipan lokal tak lain adalah kepala sekolah, guru, konselor, pengembang kurikulum, administrator, orang tua siswa, masyarakat sekitar, dan siswa.

Secara umum MBS bertujuan untuk menjadikan agar sekolah lebih mandiri atau memberdayakan sekolah melalui pemberian kewenangan (otonomi); fleksibilitas yang lebih besar kepada sekolah dalam mengelola sumber daya; dan mendorong partisipasi warga sekolah dalam mengelola sumber daya; dan mendorong partisipasi warga sekolah dan masyarakat untuk meningkatkan mutu pendidikan. (Hadiyanto, 2004: 70).

Selanjutnya, ciri-ciri MBS bisa dilihat dari sudut sejauh mana sekolah tersebut dapat mengoptimalkan kinerja organisasi sekolah, pengelolaan sumber daya manusia (SDM), proses belajar-mengajar dan sumber daya sebagaimana digambarkan dalam tabel berikut:
Tabel 2. 1

\section{Indikator Sekolah Yang Melaksanakan MBS}

\begin{tabular}{|c|c|c|c|}
\hline $\begin{array}{l}\text { Organisasi } \\
\text { Sekolah }\end{array}$ & $\begin{array}{l}\text { Proses Belajar } \\
\text { mengajar }\end{array}$ & $\begin{array}{l}\text { Sumber } \\
\text { Daya Ma- } \\
\text { nusia }\end{array}$ & $\begin{array}{l}\text { Sumber Daya } \\
\text { danAdminis- } \\
\text { trasi }\end{array}$ \\
\hline $\begin{array}{l}\text { Menyusun } \\
\text { rencana } \\
\text { sekolah } \\
\text { dan meru- } \\
\text { muskan } \\
\text { kebijakan } \\
\text { untuk } \\
\text { sekolahnya } \\
\text { sendiri }\end{array}$ & $\begin{array}{l}\text { Mengembang- } \\
\text { kan } \\
\text { kurikulum yang } \\
\text { cocok dan } \\
\text { tanggap terh- } \\
\text { adap } \\
\text { kebutuhan } \\
\text { siswa } \\
\text { dan masyarakat }\end{array}$ & $\begin{array}{l}\text { Memiliki staf } \\
\text { dengan } \\
\text { w a w a s a n } \\
\text { MBS }\end{array}$ & $\begin{array}{l}\text { Mengelola } \\
\text { dana } \\
\text { sekolah } \\
\text { secara } \\
\text { efektif dan } \\
\text { efisien }\end{array}$ \\
\hline $\begin{array}{l}\text { Menjamin } \\
\text { adanya } \\
\text { komunikasi } \\
\text { yang } \\
\text { efektif } \\
\text { antara } \\
\text { sekolah } \\
\text { dan mas- } \\
\text { yarakat }\end{array}$ & $\begin{array}{l}\text { Menyelengga- } \\
\text { rakan } \\
\text { pembelajaran } \\
\text { yang } \\
\text { efektif }\end{array}$ & $\begin{array}{l}\text { Menyediakan } \\
\text { kegiatan } \\
\text { untuk } \\
\text { pengemban- } \\
\text { gan } \\
\text { profesi pada } \\
\text { semua } \\
\text { staf }\end{array}$ & $\begin{array}{l}\text { Menyediakan } \\
\text { dukungan } \\
\text { administratif }\end{array}$ \\
\hline $\begin{array}{l}\text { Mengger- } \\
\text { akkan } \\
\text { partisipasi } \\
\text { masyarakat }\end{array}$ & $\begin{array}{l}\text { Menyediakan } \\
\text { program } \\
\text { pengembangan } \\
\text { yang diperlukan } \\
\text { siswa }\end{array}$ & $\begin{array}{l}\text { Menjamin } \\
\text { kesejahter- } \\
\text { aan staf } \\
\text { dan siswa }\end{array}$ & $\begin{array}{l}\text { Mengelola } \\
\text { dan } \\
\text { memelihara } \\
\text { gedung dan } \\
\text { sarana }\end{array}$ \\
\hline $\begin{array}{l}\text { Menjamin } \\
\text { terpeliha- } \\
\text { ranya } \\
\text { sekolah } \\
\text { yang } \\
\text { bertanggu- } \\
\text { ng jawab } \\
\text { kepada } \\
\text { masyarakat } \\
\text { dan pemer- } \\
\text { intah }\end{array}$ & $\begin{array}{l}\text { Berperanserta } \\
\text { dalam memo- } \\
\text { tivasi } \\
\text { siswa }\end{array}$ & $\begin{array}{l}\text { Menyeleng- } \\
\text { garakan } \\
\text { forum /di- } \\
\text { skusi untuk } \\
\text { membahas } \\
\text { kemajuan } \\
\text { kinerja seko- } \\
\text { lah }\end{array}$ & \\
\hline
\end{tabular}

Sumber: Modul MBS yang dikutip dari Focus on School; The Future Organization of

Education Service for Student, Department of Education, Queensland, Australia. 
MBS yang akan dikembangkan merupakan bentuk alternatif pengelolaan sekolah dalam program desentralisasi bidang pendidikan, yang ditandai dengan adanya otonomi luas di tingkat sekolah, partisipasi masyarakat yang tinggi namun masih dalam kerangka kebijakan pendidikan nasional. MBS harus mengakibatkan peningkatan proses belajar mengajar sehingga hasil belajarpun meningkat.

\section{II.4.Relasi Desentralisasi Pendidikan dan Ma- najemen Berbasis Sekolah}

Pada dasarnya MBS merupakan inti dari pelaksanaan desentralisasi pendidikan. Rondinelli dan Chema (1983) mengemukakan bahwa konsep desentralisasi pendidikan adalah transfer atau pengalihan kewenangan kepada sekolah tentang planning, manajemen, pengelolaan potensi sumber daya, dan pengalokasian anggaran. Sedangkan, desentralisasi pendidikan adalah kewenangan dalam hal penanganan isu-isu manajemen pendidikan di daerah dan pengambilan keputusan dengan melibatkan stakeholders tanpa keluar atau menyimpang dari peraturan pemerintah pusat (Unesco, 1999).

Konsep MBS dikembangkan atas dasar hasil pengkajian dan penelitian yang didasarkan adanya kecenderungan desentralisasi pendidikan. Konsep MBS ternyata memberikan hasil pendidikan yang lebih baik daripada sistem sentralisasi atau terpusat (Caldwell dan Spinks, 1992). Terdapat hubungan yang signifikan antara kewenangan pengambilan keputusan dengan pengalokasian dan pengaturan sumber daya pendidikan di sekolah, seperti material, teknologi, waktu, keuangan, dan lain-lain.

Dalam hubungannnya dengan desentralisasi pendidikan ini, MBS menurut Hallinger, Murphy, dan Hausman (1992) adalah pemberian kewenangan kepada sekolah untuk kebebsan menata organisasi sekolah, manajemen persekolahan, pengelolaan kelas, optimalisasi kerjasama(kepala sekolah, orang tua, dan guru), dan pemberian kesempatan yang kreatif dan inovatif kepada sekolah.

Sementara itu, Caldwell dan Spinks (1992) berpandangan bahwa desentralisasi dalam hal sekolah membuat kerangka kerja untuk tingkat lokal sekolah dan disesuaikan dengan peraturan yang ada di pusat, termasuk di dalamnya adalah tentang (1) pengetahuan (knowledge) yaitu desentralisasi yang berhubungan dengan kurikulum, dikaitkan dengan tujuan kurikuler dan sekolah; (2) teknologi, yaitu desentralisasi yang berhubungan dengan teknik belajar mengajar, (3) kekuatan (power), yakni desentralisasi tentang kewenangan membuat keputusan; (4) bahan (materials), desentralisasi yang terkait dengan penggunaan fasilitas, pengadaan, dan peralatan; (5) masyarakat (people), desentralisasi yang terkait denga sumber daya manusia, pengembangan kemampuan proses pembelajaran (PBM) guru, dan dukungan dalam PBM; (6) waktu (time), yaitu desentralisasi yang berkaitan dengan pengalokasian waktu, dan (7) keuangan (finance), yakni desentralisasi yang berhubungan dengan pengalokasian anggaran.

\section{METODE PENELITIAN}

Dalam penelitian ini yang menjadi sumber data adalah subjek dari mana data yang diperoleh. Responden dan informan dalam penelitian ini adalah Kepala Dinas Pendidikan Kota Sawahlunto, Kabid Pendidikan Menengah dan Tinggi, Kepala Sekolah SMA Negeri 1 Sawahlunto, Waka Bidang Kurikulum SMA Negeri 1 Sawahlunto. Pengumpulan data adalah merupakan suatu proses sistematis untuk memperoleh data-data yang diperlukan dalam penelitian. Data atau bukti yang diperlukan dalam penelitian ini menggunakan multi sumber bukti (Robert K. 
Yin, 2005). Adapun sumber-sumber data yang digunakan untuk memperoleh informasi dan bukti dalam penelitian terdiri atas 2 (dua) sumber data, yaitu : Wawancara dan Dokumentasi.

\section{PEMBAHASAN}

Desentralisasi adalah pelimpahan kewenangan dari Pusat ke Daerah. Adapun dasar pelaksanaan desentralisasi pendidikan adalah UU No. 22 Tahun 1999 tentang Pemerintahan Daerah jo UU No. 32 Tahun 2004 tentang Pemerintahan Daerah. Dimana pada Pasal 14 UU No. 32 Tahun 2004 dinyatakan urusan pemerintahan pemerintah kabupaten/kota yang bersifat wajib dan pilihan. Urusan pemerintahan yang bersifat wajib mencakup urusan-urusan yang berskala kabupaten/kota yang diantaranya adalah penyelenggaraan bidang pendidikan dan alokasi Sumber Daya Manusia (SDM) potensial. Dari situ jelas terdapat pelimpahan kewenangan dari Pusat ke Daerah dalam hal penyelenggaraan desentralisasi pendidikan.

Sasaran pelimpahan kewenangan tersebut tercakup dalam sebuah kesatuan hukum yaitu Pemerintah Kabupaten/Kota dan masyarakat. Oleh sebab itu komitmen Kepala Daerah dalam pelaksanaan pendidikan akan memberikan warna dan corak pendidikan tersendiri bagi peningkatan kualitas pendidikan. Demikian halnya di Kota Sawahlunto, otonomi daerah mengisyaratkan kemungkinan adanya pengembangan suatu wilayah dalam suasana yang kondusif termasuk pengelolaan dan pengembangan bidang pendidikan, dimana UU No. 32 Tahun 2004 tentang Pemerintahan Daerah menuntut adanya perubahan pengelolaan pendidikan dari sentralistik menjadi desentralistik.

Salah satu desentralisasi yang dilaksanakan di Kota Sawahlunto adalah desentralisasi dalam hal pengelolaan pendidikan. Pada pelaksanaann- ya, desentralisasi sesuai dengan UU No. 32 Tahun 2004 Pasal 14 yang telah menetapkan urusan pemerintahan pemerintah Kabupaten/Kota yang bersifat wajib dan pilihan. Urusan pemerintahan yang bersifat wajib mencakup urusan-urusan berskala Kabupaten/Kota yang salah satunya adalah "Penyelenggaraan bidang pendidikan dan alokasi SDM potensial."

Selanjutnya berdasarkan Peraturan Pemerintah No. 38 Tahun 2007 tentang Pembagian Urusan Pemerintahan Antara Pemerintah, Pemerintahan Daerah Provinsi, dan Pemerintahan Daerah Kabupaten/Kota juga telah dijelaskan mengenai pembagian urusan pemerintahan di bidang pendidikan. Sebagaimana PP tersebut, Pemerintah Kota Sawahlunto selaku Pemerintah Daerah Kota/Kabupaten memiliki urusan dan kewenangan sebagai berikut:

1) Menetapkan kebijakan operasional, perencanaan operasional pendidikan,

2) Penyelenggaraan dan/atau pengelolaan pendidikan berbasis keunggulan lokal pada pendidikan dasar dan menengah,

3) Pengawasan pelaksanaan kurikulum tingkat satuan pendidikan pada pendidikan dasar, pembinaan dan pengembangan pendidik dan tenaga kependidikan pendidikan anak usia dini, pendidikan dasar, pendidikan menengah dan pendidikan nonformal,

4) Koordinasi, fasilitasi, monitoring, dan evaluasi pelaksanaan ujian sekolah skala Kabupaten/Kota,

Urusan dan kewenangan yang dimiliki oleh Pemerintah Kota tersebut dilimpahkan ke Dinas Pendidikan Kota. Sebagaimana yang tercantum pada Pasal 3 PP No. 38 Tahun 2007, urusan pemerintahan yang diserahkan kepada daerah disertai dengan sumber pendanaan, pengalihan sarana dan prasarana, serta kepegawaian. Setelah dilimpahkannya kewenangan dari Pe- 
merintah Kota ke Dinas Pendidikan Kota, maka selanjutnya Dinas Pendidikan merupakan unsur pelaksana Pemerintah Kota Sawahlunto dalam melaksanakan pengelolaan pendidikan. Dinas Pendidikan Kota Sawahlunto selanjutnya mempunyai tugas pokok mempersiapkan, menyusun, dan merumuskan kebijakan dan melaksanakan kewenangan dibidang pendidikan. Sedangkan fungsi Dinas Pendidikan Kota Sawahlunto sebagaimana tercantum dalam Peraturan Daerah No. 2 tahun 2008 tentang Susunan Organisasi Perangkat Daerah Kota Sawahlunto adalah:

a. Perumusan kebijaksanaan teknis di bidang pendidikan, pemuda dan olahraga,

b. Penyelenggara urusan Pemerintahan Daerah dan pelayanan umum di bidang pendidikan, pemuda dan olahraga,

c. Pembinaan dan pelaksanaan tugas bidang pendidikan, pemuda dan olahraga; dan

d. Pelaksanaan tugas lain yang diberikan oleh Walikota sesuai dengan tugas dan fungsinya.

Dengan adanya pembagian urusan yang jelas di bidang pendidikan, Dinas Pendidikan bisa membuat program kerja sebagai acuan kerja instansinya sehingga bisa dilihat dengan program kerja yang telah disusun dan dilaksanakan tersebut, desentralisasi dalam pengelolaan pendidikan dapat dilaksanakan dengan baik. Dari sini selanjutnya diketahui mekanisme penyerahan urusan dan kewenangan dalam pengelolaan pendidikan tersebut. Dimana adanya pembagian urusan pemerintahan bagi pemerintah, pemerintah daerah provinsi, dan pemerintah kabupaten/kota mengenai pembagian urusan pemerintahan di bidang pendidikan.

Dari urusan dan kewenangan ini selanjutnya Pemerintah Kota Sawahlunto melimpahkannya ke Dinas Pendidikan. Pada tahapan berikutnya Dinas Pendidikan dapat membuat program ker- ja sebagai acuan kerja instansinya sehingga bisa dilihat dengan program kerja yang telah disusun dan dilaksanakan tersebut, desentralisasi dalam pegelolaan pendidikan dapat dilaksanakan dengan baik.

Adapun Program kerja Dinas Pendidikan Kota Sawahlunto sesuai dengan Rencana Kerja Pemerintah Daerah (RKPD) Kota Sawahlunto adalah:

1. Peningkatan daya tampung peserta didik pada setiap tingkat pendidikan,

2. Pengurangan angka putus sekolah melalui pemberian beasiswa bagi anak yang berasal dari keluarga miskin, pelaksanaan program BOS, pemberian subsidi wajib belajar,

3. Pelaksanaan pendidikan luar sekolah,

4. Peningkatan kompetensi, kualifikasi, dan sertifikasi guru,

5. Peningkatan kualitas Proses Belajar Mengajar (PBM),

6. Peningkatan kuantitas dan kualitas sarana prasarana sekolah,

7. Peningkatan Manajemen Berbasis Sekolah (MBS),

8. Peningkatan pelestarian nilai-nilai budaya, adat dan agama,

9. Pengembangan budaya baca dan pembinaan perpustakaan,

10. Peningkatan peran serta kepemudaan,

11. Pengembangan kebijakan dan manajemen olahraga,

12. Peningkatan sarana dan prasarana olahraga.

Dari program Dinas Pendidikan ini selanjutnya dilaksanakan berbagai kegiatan. Seperti halnya pelaksanaan ujian standar kota dilaksanakan pada program peningkatan kualitas proses belajar mengajar. Sedangkan penetapan kebijakan operasional dan perencanaan operasional pendidikan melalui program dan inovasi pendidikan 
yang telah disusun oleh Dinas Pendidikan Kota Sawahlunto secara keseluruhan.

Di masa otonomi daerah dengan adanya desentralisasi dalam manajemen (pengelolaan) pendidikan, maka Pemerintah Kota Sawahlunto melaksanakan manajemen, pengarahan, dan monitoring terhadap seluruh aparatur pendidikan sehingga mampu memberikan layanan pendidikan yang optimal, dan meningkatkan efisiensi melalui penataan pelaksanaan pendidikan yang sehat dan akuntabel. Hal ini karena Pemerintah Kota Sawahlunto sangat mendorong tumbuh dan berkembangnya otonomi satuan pendidikan untuk dapat meningkatkan pembelajaran yang bermutu, dalam kapasitas ini melalui program peningkatan Manajemen Berbasis Sekolah (MBS).

Dalam penelitian ini, pelaksanaan Manajemen Berbasis Sekolah (MBS) akan dilihat pada jenjang pendidikan menengah, yakni pada SMA Negeri 1 Sawahlunto. Untuk melihat pelaksanaan Manajemen Berbasis Sekolah (MBS) tentu semua aspek pendidikan yang dianalisis dengan tahapan-tahapan atau proses manajemen atau juga dapat dikatakan fungsi manajemen. Sebagaimana konsep Manajemen Berbasis Sekolah (MBS), berikut ini dilihat pelaksanaan sesuai dengan tahapan-tahapan/proses manajemen:

Tahap pertama adalah pereencanaan. Perencanaan merupakan pemilihan atau penetapan tujuan organisasi dan penentuan strategi, kebijaksanaan, program, prosedur, dan anggaran untuk mencapai tujuan. Pembuatan keputusan banyak terlibat dalam fungsi ini. Sebagai suatu organisasi, SMA Negeri 1 Sawahlunto telah menetapkan tujuan situasional sekolah, yaitu diantaranya: (1) Memperoleh rata-rata nilai pada Surat Tanda Kelulusan mencapai nilai 8.00; (2) Menjadi model inovasi dan perubahan proses pembelajaran dan manajemen peningkatan mutu sekolah, (3) Menjadi sekolah yang mengintegrasikan Pening- katan Kualitas Pendidikan Bernuansa Surau (PKPBS) dan Pendidikan Berbasis Keunggulan Lokal (PBKL), (4) Menjadi sekolah yang seluruh komponen sekolah memahami dan terampil menggunakan program-program aplikasi komputer sesuai dengan tugas dan fungsi masing-masing, (5) Memiliki sistem manajemen informasi yang terkomputerisasi.

Untuk mencapai semua tujuan tersebut dibutuhkan kebijaksanaan, program, prosedur, metode, dan anggaran agar tujuan yang diharapkan dapat tercapai sebagaimana mestinya. Adapun kesemua itu (kebijaksanaan, program, prosedur, metode, dan anggaran) telah dirumuskan melalui Rencana Anggaran Pendapatan Belanja Sekolah (RAPBS) SMA Negeri 1 Sawahlunto di setiap tahun anggaran. RAPBS selanjutnya merupakan kebijaksanaan yang diambil Kepala Sekolah beserta jajarannya untuk memberikan kejelasan arah bagi setiap kegiatan, sehingga setiap kegiatan dapat diusahakan dan dilaksanakan seefisien dan seefektif mungkin.

Selnjutnya adalah tahap pengorganisasian (organizing). Hal yang penting untuk diperhatikan dalam pengorganisasian adalah bahwa setiap kegiatan harus jelas siapa yang mengerjakan, kapan dikerjakan, dan apa targetnya. Di SMA Negeri 1 Sawahlunto, pengorganisasian juga dilakukan untuk melengkapi rencana-rencana yang telah dibuat seperti tertuang pada Rencana Anggaran Pendapatan Belanja Sekolah (RAPBS) hingga kemudian disyahkan oleh Dinas Pendidikan Kota Sawahlunto menjadi Anggaran Pendapatan Belanja Sekolah (APBS). Setelah menjadi APBS kemudian menjadi suatu program kerja tahunan sekolah. Pada program kerja tahunan sekolah ini diketahui dengan jelas siapa yang mengerjakan, kapan dikerjakan, dan apa targetnya. Seperti pada program kerja tahunan SMA Negeri 1 Sawahlunto terdapat komponen, sub komponen, uraian ke- 
giatan, tanggal dan waktu pelaksanaan, harga/anggaran, penanggung jawab, sumber pembiayaan, dan indikator keberhasilannya.

Dari seluruh rangkaian fungsi manajemen, pelaksanaan (Actuating) merupakan fungsi manajemen yang paling utama. Dalam fungsi perencanaan dan pengorganisasian lebih banyak berhubungan dengan aspek-aspek abstrak proses manajemen, sedangkan fungsi pelaksanaan justru lebih menekankan pada kegiatan yang berhubungan langsung dengan orang-orang dalam organisasi. SMA Negeri 1 Sawahlunto melaksanakan fungsi pelaksanaan ini dengan melalui mekanisme dimana Kepala Sekolah memberikan pengarahan dan motivasi kepada seluruh jajarannya pada suatu rapat konsolidasi mingguan dan rapat konsolidasi bulanan hingga rapat evaluasi yang dilaksanakan satu kali satu tahun. Melalui mekanisme ini jajaran sekolah diharapkan dapat melaksanakan program kerja tahunan yang telah disusun dengan optimal sesuai dengan peran, tugas, dan tanggung jawabnya masing-masing.

Pengawasan dalam hal ini merupakan suatu kegiatan yang berusaha untuk mengendalikan agar pelaksanaan dapat berjalan sesuai dengan rencana dan memastikan apakah tujuan organisasi tercapai. Apabila terjadi penyimpangan dimana letak penyimpangannya itu, dan selanjutnya bagaimana pula tindakan yang diperlukan untuk mengatasinya. Rapat konsolidasi sekolah baik dalam rapat konsolidasi mingguan, rapat konsolidasi bulanan, maupun rapat evaluasi tahunan adalah suatu bentuk pelaksanaan fungsi pengawasan di SMA Negeri 1 Sawahlunto.” Dengan dilaksanakannya rapat konsolidasi sekolah ini dapat melihat sejauh mana suatu pelaksanaan kegiatan dapat berjalan sesuai dengan yang telah direncanakan.

Selain itu, dari rapat konsolidasi yang dilaksanakan secara kontinyu ini akan diketahui juga pencapaian tujuan sekolah yang telah ditetapkan pada tataran perencanaan sebagaimana yang telah dipaparkan di atas. Selanjutnya apabila terjadi penyimpangan dalam pelaksanaan suatu kegiatan, dapat diambil tindakan yang diperlukan untuk mengatasinya.

Fungsi-fungsi manajemen ini berjalan saling berinteraksi dan saling kait-mengkait antara satu dengan lainnya, sehingga menghasilkan proses manajemen. Dengan demikian, proses manajemen sebenarnya merupakan proses interaksi antara berbagai fungsi manajemen tersebut. Dalam perspektif persekolahan, agar tujuan pendidikan di sekolah dapat tercapai secara efektif dan efisien, maka proses manajemen pendidikan memiliki peranan yang amat vital. Karena bagaimanapun sekolah merupakan suatu sistem yang di dalamnya melibatkan berbagai komponen dan sejumlah kegiatan yang perlu dikelola secara baik dan tertib. Sekolah tanpa didukung proses manajemen yang baik, boleh jadi hanya akan menghasilkan kesemrawutan laju organisasi, yang pada gilirannya tujuan pendidikan pun tidak akan pernah tercapai sebagaimana mestinya. Dengan demikian, setiap kegiatan pendidikan di sekolah harus memiliki perencanaan yang jelas dan realistis, pengorganisasian yang efektif dan efisien, pengerahan dan pemotivasian seluruh personil sekolah untuk selalu dapat meningkatkan kualitas kinerjanya, dan pengawasan yang berkelanjutan.

Sebagaimana konsep Focus on School; The Future Organization of Education Service for Student, Department of Education, Queensland, Australia, indikator terlaksananya Manajemen Berbasis Sekolah (MBS) bisa dilihat dari sudut sejauh mana sekolah tersebut dapat mengoptimalkan (1) kinerja organisasi sekolah, (2) pengelolaan sumber daya manusia (SDM), (3) proses belajar-mengajar, dan (4) sumber daya adminis- 
trasi. Dalam hal ini SMA Negeri 1 Sawahlunto mengusahakan pelaksanaan keempat indikator ini dalam pelaksanaan MBS.

Dalam program peningkatan Manajemen Berbasis Sekolah (MBS), SMA Negeri 1 Sawahlunto sebagai salah satu jenjang pendidikan menengah di Kota Sawahlunto sendiri melaksanakan: (1) Manajemen Pelayanan Pendidikan yang Berbasis Sekolah, dan (2) Peningkatan Mutu Tenaga Pendidik dan Tenaga Kependidikan. Meskipun sudah ada upaya dalam pelaksanaan MBS di SMA Negeri 1 Sawahlunto masih ditemukan kendala dalam pelaksanaannya, yaitu:

a. Tidak Berminat Untuk Terlibat.

Sebagian orang tidak menginginkan kerja tambahan selain pekerjaan yang sekarang mereka lakukan. Mereka tidak berminat untuk ikut serta dalam kegiatan yang menurut mereka hanya menambah beban. Anggota Komite Sekolah harus lebih banyak menggunakan waktunya dalam hal-hal yang menyangkut perencanaan dan anggaran. Akibatnya kepala sekolah dan guru tidak memiliki banyak waktu lagi yang tersisa untuk memikirkan aspek-aspek lain dari pekerjaan mereka.

b. Tidak Efisien

Pengambilan keputusan yang dilakukan secara partisipatif adakalanya menimbulkan frustrasi dan seringkali lebih lamban dibandingkan dengan cara-cara yang otokratis. Para anggota Komite Sekolah harus dapat bekerja sama dan memusatkan perhatian pada tugas, bukan pada hal-hal lain di luar itu.

c. Memerlukan Pelatihan

Pihak-pihak yang berkepentingan kemungkinan besar sama sekali tidak atau belum berpengalaman menerapkan model yang rumit dan partisipatif ini. Mereka kemungkinan besar tidak memiliki pengetahuan dan ket- erampilan tentang hakikat MBS sebenarnya dan bagaimana cara kerjanya, pengambilan keputusan, komunikasi, dan sebagainya.

d. Kebingungan Atas Peran dan Tanggung Jawab Baru

Pihak-pihak yang terlibat kemungkinan besar telah sangat terkondisi dengan iklim kerja yang selama ini mereka geluti. Penerapan MBS mengubah peran dan tanggung jawab pihak-pihak yang berkepentingan. Perubahan yang mendadak kemungkinan besar akan menimbulkan kejutan dan kebingungan sehingga mereka ragu untuk memikul tanggung jawab pengambilan keputusan.

\section{e. Kesulitan Koordinasi}

Setiap penerapan model yang rumit dan mencakup kegiatan yang beragam mengharuskan adanya koordinasi yang efektif dan efisien. Tanpa itu, kegiatan yang beragam akan berjalan sendiri ke tujuannya masing-masing yang kemungkinan besar sama sekali menjauh dari tujuan sekolah.

Penerapan MBS yang efektif seyogyanya dapat mendorong kinerja kepala sekolah dan guru yang pada gilirannya akan meningkatkan prestasi siswa. Oleh sebab itu, harus ada keyakinan bahwa MBS memang benar-benar akan berkontribusi bagi peningkatan prestasi siswa. Ukuran prestasi harus ditetapkan multidimensional, jadi bukan hanya pada dimensi prestasi akademik. Dengan taruhan seperti itu, daerah-daerah yang hanya menerapkan MBS sebagai "mode" akan memiliki peluang yang kecil untuk berhasil. Dari pelaksanaan MBS di SMA Negeri 1 Sawahlunto diperoleh kekuatan dari pelaksanaan MBS:

a. Memungkinkan orang-orang yang kompeten di sekolah untuk mengambil keputusan yang akan meningkatkan pembelajaran.

b. Memberi peluang bagi seluruh anggota se- 
kolah untuk terlibat dalam pengambilan keputusan penting.

c. Mendorong munculnya kreativitas dalam merancang bangun program pembelajaran.

d. Mengarahkan kembali sumber daya yang tersedia untuk mendukung tujuan yang dikembangkan di sekolah.

e. Menghasilkan rencana anggaran yang lebih realistik ketika orang tua dan guru makin menyadari keadaan keuangan sekolah, batasan pengeluaran, dan biaya program-program sekolah.

f. Meningkatkan motivasi guru dan mengembangkan kepemimpinan.

Dengan diidentifikasinya kendala dan kekuatan dalam pelaksanaan MBS, selanjutnya dibutuhkan strategi pelaksanaan MBS agar dapat meningkatkan mutu pendidikan. Adapun strategi pelaksanaan MBS di SMA 1 Sawahlunto khususnya dan Kota Sawahlunto pada umunya ke depan adalah sebagai berikut:

1. Menciptakan prakondisi yang kondusif untuk dapat menerapkan MBS, yakni peningkatan kapasitas dan komitmen seluruh warga sekolah, termasuk masyarakat dan orangtua siswa. Upaya untuk memperkuat peran kepala sekolah harus menjadi kebijakan yang mengiringi penerapan kebijakan MBS. "An essential point is that schools and teachers will need capacity building if school-based management is to work". Demikian De grouwe menegaskan.

2. Membangun budaya sekolah (school culture) yang demokratis, transparan, dan akuntabel. Termasuk membiasakan sekolah untuk membuat laporan pertanggungjawaban kepada masyarakat. Model memajangkan RAPBS di papan pengumuman sekolah yang dilakukan merupakan salah satu tahap awal yang sangat positif. Juga membuat laporan secara insidental berupa booklet, leaflet, atau poster tentang rencana kegiatan sekolah. Alangkah serasinya jika kepala sekolah dan ketua Komite Sekolah dapat tampil bersama dalam media tersebut.

3. Pemerintah pusat lebih memainkan peran monitoring dan evaluasi. Dengan kata lain, pemerintah pusat dan pemerintah daerah perlu melakukan kegiatan bersama dalam rangka monitoring dan evaluasi pelaksanaan MBS di sekolah.

4. Mengembangkan model program pemberdayaan sekolah. Model pemberdayaan sekolah berupa pendampingan atau fasilitasi dinilai lebih memberikan hasil yang lebih nyata dibandingkan dengan pola-pola lama berupa penataran MBS.

\section{KESIMPULAN}

1. Pemerintah Kota Sawahlunto saat ini masih mengupayakan pelaksanakan desentralisasi dalam pengelolaan pendidikan. Pendidikan sendiri dalam hal ini merupakan prioritas utama dalam pembangunan Kota Sawahlunto Tahun 2008-2013. Pemerintah Kota Sawahlunto pada saat ini melaksanakan "tiga pilar pembangunan pendidikan."

2. Pelaksanaan desentralisasi dalam hal pengelolaan pendidikan khususnya pelaksanaan Manajemen Berbasis Sekolah (MBS) pada jenjang pendidikan menengah di Kota Sawahlunto saat ini masih memiliki kelemahan-kelemahan antara lain masih rendahnya partisipasi masyarakat dalam pembangunan pendidikan di sekolah.

3. Sesuai dengan Rencana Kerja Pemerintah Daerah (RKPD), Program Peningkatan Manajemen Berbasis Sekolah (MBS) merupakan salah satu program Dinas Pendidikan 
Kota Sawahlunto dalam rangka pelaksanaan penguatan tata kelola, akuntabilitas, dan citra publik pendidikan.

4. Dalam upaya peningkatan Manajemen Berbasis Sekolah (MBS), SMA Negeri 1 Sawahlunto sebagai salah satu jenjang pendidikan menengah di Kota Sawahlunto melaksanakan: (1) Manajemen Pelayanan Pendidikan yang Berbasis Sekolah, dan (2) Peningkatan Mutu Tenaga Pendidik dan Tenaga Kependidikan.

\section{DAFTAR KEPUSTAKAAN}

Ahmad, Ali Riyadi. Politik Pendidikan, Menggugat Birokrasi Pendidikan Nasional, Ar-Ruzz. Yogyakarta, 2006.

Afriani. Kinerja Program Dinas Pendidikan Di Era Otonomi Daerah (Kasus Pada Dinas Pendidikan Kota Bukittinggi), Skripsi pada Jurusan Ilmu Politik Unand. 2008.

Bungin, Burhan. Analisis Data Penelitian Kualitatif, Jakarta, RajaGrafindo Persada, 2002.

Chan, Sam M. dan Tuti T Sam. Analisis SWOT Kebijakan Pendidikan Era Otonomi Daerah, Jakarta, RajaGrafindo Persada, 2005.

Cresswell, John W. Research Design, qualitative and Quantitative Approaches, Jakarta, KIK Press.

Fadila. Identifikasi Pelaksanaan Program Kerja Dewan Pendidikan Dan Komite Sekolah Dalam Penyelenggaraan Desentralisasi Pendidikan (Studi Kasus Pada Jenjang Pendidikan Menengah Di Kota Sawahlunto Periode 2006). Skripsi pada Jurusan 1mu Politik Unand Padang. 2007.

Hasbullah. Otonomi Pendidikan, Jakarta, PT. Raja Grafindo Persada, 2006.

Kabullah, M. Ichsan. Bias Pelayanan Pendidikan Sekolah Menengah Kejuruan (SMK) Di Provinsi Jambi. Tesis pada Program Studi
Magister Administrasi Publik UGM. 2009. Moleong, Lexy. Metodelogi Penelitian Kualitatif, Bandung, Remaja Rosda Karya, 2002.

Nurcholis, Hanif. Teori dan Praktik Pemerintahan dan Otonomi Daerah. Jakarta, Grasindo, 2005.

Peraturan Daerah Kota Sawahlunto Nomor 01 tahun 2008 tentang Susunan Organisasi Perangkat Daerah Kota Sawahlunto.

PP No. 25 Tahun 2000 tentang Kewenangan Pemerintah dan Kewenangan Pemerintah Propinsi sebagai Daerah Otonom.

Peraturan Pemerintah (PP) Nomor 19 Tahun 2005 tentang Standar Nasional Pendidikan

PP No. 38 Tahun 2007 tentang Pembagian Urusan Pemerintahan Antara Pemerintah, Pemerintahan Daerah Provinsi, dan Pemerintahan Daerah Kabupaten/Kota.

Rencana Strategis 2005-2009. Dinas Pendidikan Kota Sawahlunto. 2007.

Sirozi, M. Politik Pendidikan, Jakarta, RajaGrafindo Persada, 2005.

Syaukani. Titik Temu dalam Dunia Pendidikan, Jakarta, Nuansa Madani, 2002.

Triguno. 1999. Budaya Kerja: Menciptakan Lingkungan Yang Kondusive Untuk Meningkatkan Produktivitas Kerja. Jakarta: Golden Terayon Press.

Undang-Undang Otonomi Daerah 2004, Bandung, Citra Umbara, 2004.

Undang-Undang No. 20 Tahun 2003 tentang Sistem Pendidikan Nasional.

Yin, Robert K. Studi Kasus Desain dan Metode, Jakarta, Raja Grafindo Persada, 2005. 